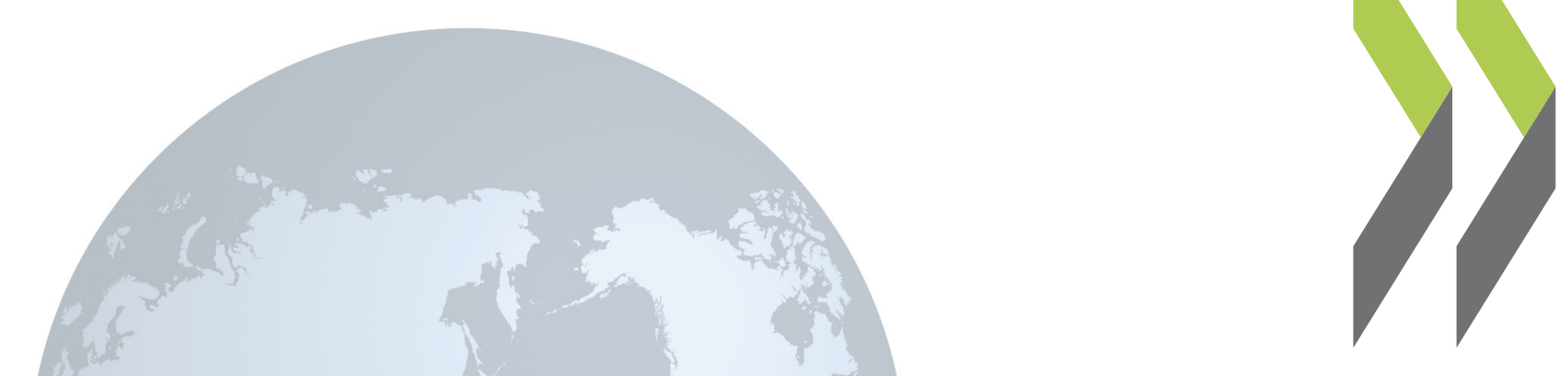

OECD Labour Market and Social Policy Occasional Papers No. 31

\title{
Key Employment Policy Challenges Faced by OECD Countries
} OECD 


\section{Unclassified}

OECD

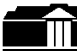

OCDE

告

Organisation de Coopération et de Développement Economiques

Organisation for Economic Co-operation and Development

DIRECTORATE FOR EDUCATION, EMPLOYMENT, LABOUR AND SOCIAL AFFAIRS

EMPLOYMENT, LABOUR AND SOCIAL AFFAIRS COMMITTEE

LABOUR MARKET AND SOCIAL POLICY - OCCASIONAL PAPERS Nº31

OECD submission to the G8 Growth, Employability and Inclusion Conference London, 21-22 February 1998
OLIS : 07-Apr-1998

Dist. : 09-Apr-1998

\section{KEY EMPLOYMENT POLICY CHALLENGES FACED BY OECD COUNTRIES}

Or. Eng. 


\title{
DIRECTORATE FOR EDUCATION, EMPLOYMENT, LABOUR AND SOCIAL AFFAIRS
}

\section{OCCASIONAL PAPERS}

This series is designed to make available to a wider readership selected labour market and social policy studies prepared for use within the OECD. Authorship is usually collective, but principal writers are named. The papers are generally available only in their original language -- English or French -- with a summary in the other.

Comment on the series is welcome, and should be sent to the Directorate for Education, Employment, Labour and Social Affairs, 2 rue André-Pascal, 75775 PARIS CEDEX 16, France. Additional, limited copies are available on request.

The opinions expressed and arguments employed here are the responsibility of the author(s) and do not necessarily reflect those of the OECD.

\begin{abstract}
Applications for permission to reproduce or translate all or part of this material should be made to:
\end{abstract}

Head of Publications Service,

OECD,

2 rue André-Pascal,

75775 PARIS CEDEX 16,

France

Copyright OECD 1998 
DEELSA/ELSA/WD(98)2

FOREWORD/AVANT-PROPOS

The organisers of the G8 Growth, Employability and Inclusion Conference, held in London on 21/22 February 1998, invited the OECD to submit a background paper. This paper which is re-printed here, is based on both past and on-going work in the Directorate for Education, Employment, Labour and Social Affairs, the Territorial Development Service and the Economics Department.

*****

Les organisateurs de la conférence du G8 sur le thème "Growth, Employability and Inclusion", tenue à Londres les 21 et 22 février 1998, ont invité l'OCDE à soumettre un document de base. Ce document, reproduit ici, est basé sur les travaux passés et en cours de la Direction de l'Education, de l'Emploi, du Travail et des Affaires sociales, du Service du Développement territorial et du Département des Affaires économiques. 


\title{
Key Employment Policy Challenges Faced by OECD Countries
}

\author{
Submission by the OECD to the \\ G8 Growth, Employability and Inclusion Conference \\ London, 21-22 February 1998
}

The problem

Lessons from implementing the Jobs Strategy

Lesson 1. It is possible to reduce high and persistent unemployment on a durable basis

Lesson 2. Most countries have taken some steps to reduce unemployment but only the "successful" countries did so on a sufficient scale

Lesson 3. Concerns about the potential trade-off between equity and efficiency lie at the heart of whether OECD countries are willing to implement all the Jobs Strategy recommendations or not

Lesson 4. There are significant complementarities to be reaped among structural reforms in different areas

Lesson 5. Macroeconomic conditions and policies and their interactions with structural policies are very important for labour market outcomes

Lesson 6. What is needed now is further political action

Some specific areas of current concern

i) Tax and benefit reform

ii) Increasing the effectiveness of active labour market policies (ALMPs)

iii) Entrepreneurship and job creation in small firms

iv) Youth labour market problems and schooling

The contrasting labour market challenges in Russia

References 


\title{
Key Employment Policy Challenges Faced by OECD Countries
}

\author{
Submission by the OECD to the \\ London G8 Jobs Conference 21-22 February 1998
}

\section{The problem}

1. OECD countries as a whole have experienced modest annual output growth of some $21 / 2$ per cent over the past four years. But unemployment remains unacceptably high -- having fallen only slightly from its peak of 38 million in 1993 to the current 35 million or 7 per cent of the workforce -- and wage and income disparities have widened in many countries, posing potential risks to social cohesion. These trends have prompted much debate on their causes, consequences and remedies.

2. These are among the issues that the OECD has analyzed and discussed with Member countries since 1992 in the context of its Jobs Strategy work. OECD Ministers have endorsed the Jobs Strategy recommendations and called last May for greater reform efforts. More recently the meeting of OECD Labour Ministers last October emphasised the need for policies for low-paid and unskilled job seekers, enhancing the effectiveness of active labour market policies and lifelong learning to maintain employability, issues which were also taken up last November at the Kobe Jobs Conference.

3. The lessons from implementing the Jobs Strategy, which are reviewed in the first section below, can be summarised simply -- success requires sustained use of a broad range of policies, many of which will bear fruit only over the longer term. The practical lessons to be learned from the different experiences of OECD countries go some way to answering the question posed to us by the Conference organisers as to why some countries have greater success than others in creating jobs. The bottom line is that reducing unemployment durably is possible, and that policies to this end should be pursued vigorously in the years to come. A set of other, more specific questions -concerning tax-benefit interactions, the effectiveness of active labour market policies, entrepreneurship and job creation in small firms and youth labour markets -- were also posed, and are treated in the second section. These more specific issues are nevertheless linked and underline the key message of the Jobs Strategy that reforms must be comprehensive, country-specific and on many fronts, if they are to succeed. 


\section{Lessons from implementing the Jobs Strategy}

4. The OECD Jobs Study, which was approved by OECD Ministers and published in 1994, developed a wide-ranging strategy for reducing high and persistent unemployment and increasing living standards. Building on the more than 60 detailed policy recommendations contained in the Jobs Study, the OECD Jobs Strategy has been articulated around ten broad orientations for macroeconomic and structural policies (see Box 1). Since the publication of the Jobs Study, the OECD Secretariat has undertaken further analyses in a number of these areas (such as active labour market policies and the interplay between taxes and benefits -- see full list of references at the end) in order to refine its diagnosis and policy recommendations.

5. Considerable effort has also been devoted, in close co-operation with OECD Member countries, to developing and monitoring the implementation of concrete policy recommendations tailored to the specific circumstances in each country. Six key lessons from this detailed countryby-country review are set out below. They throw considerable light on the general issues of why some countries have had more success than others in creating jobs and reducing unemployment, and on the most important factors underlying such success (see Implementing the OECD Jobs Strategy: Lessons from Member Countries' Experience).

\section{Box 1. The OECD Jobs Strategy}

1. Set macroeconomic policy such that it will both encourage growth and, in conjunction with good structural policies, make it sustainable, i.e. non-inflationary.

2. Enhance the creation and diffusion of technological know-how by improving frameworks for its development.

3. Increase flexibility of working-time (both short-term and lifetime) voluntarily sought by workers and employers.

4. Nurture an entrepreneurial climate by eliminating impediments to, and restrictions on, the creation and expansion of enterprises.

5. Make wage and labour costs more flexible by removing restrictions that prevent wages from reflecting local conditions and individual skill levels, in particular of younger workers.

6. Reform employment security provisions that inhibit the expansion of employment in the private sector.

7. Strengthen the emphasis on active labour market policies and reinforce their effectiveness.

8. Improve labour force skills and competences through wide-ranging changes in education and training systems.

9. Reform unemployment and related benefit systems -- and their interactions with the tax system -- such that societies' fundamental equity goals are achieved in ways that impinge far less on the efficient functioning of the labour markets.

10. Enhance product market competition so as to reduce monopolistic tendencies and weaken insider-outsider mechanisms while also contributing to a more innovative and dynamic economy. 
Lesson 1: It is possible to reduce high and persistent unemployment on a durable basis.

6. This lesson runs counter to the prevailing sense of pessimism about tackling high and persistent unemployment which one encounters nowadays in many countries. But there are enough success stories around to put the lie to this pessimism.

7. A key economic indicator which was focused upon in reviewing country experience was the change in the estimated "structural unemployment rate". As shown in Table 1 overleaf, it has risen in eleven countries since 1990, shown little change in another eight countries, and decreased significantly in four. The last group, the "success stories", are Ireland, the Netherlands, New Zealand and the United Kingdom. Note that these country groupings are determined in terms of significant changes in the estimated structural unemployment rate. It is also important to emphasise the level of the structural unemployment rate. When this latter indicator is taken into account, countries such as the United States, Japan and Norway should be added to the list of "success stories" since policy settings in these countries managed not only to prevent a significant rise in structural unemployment from occurring in the first place, but also to reduce actual unemployment. Over time, other countries should be added to the list of "successes" as they implement macroeconomic and structural policies which permit a durable reduction of unemployment.

\section{Lesson 2: Most countries have taken some steps to reduce unemployment but only the "successful" countries did so on a sufficient scale.}

8. There are some important common features in the experiences of the four "success stories". These common features include:

i) reform programmes were implemented against the background of serious economic disequilibria in the late 1970s and early 1980s when it became clear that existing policy settings were no longer viable;

ii) all four countries put in place stability-oriented macroeconomic policy frameworks which focused on reducing public sector deficits and debt and controlling inflation;

iii) they have all implemented a broad range of structural reforms in labour and product markets, though the extent and depth of these reforms have varied significantly across the four countries;

iv) they have been willing to undertake reforms that moderate the bargaining power of labour market insiders with, in the case of Ireland and the Netherlands, the cooperation of the social partners;

in all four cases, it has taken quite a long time, sometimes up to a decade or more, for the benefits of comprehensive reforms to show up in significant declines in both the estimated structural unemployment rate and reductions in the actual numbers of those unemployed. 
DEELSA/ELSA/WD(98)2

Table 1. Estimated structural unemployment in the OECD countries, $1986-96^{1}$

\begin{tabular}{|c|c|c|c|c|}
\hline \multicolumn{5}{|c|}{ In the nineties the structural unemployment rate has ... } \\
\hline & & 1986 & 1990 & 1996 \\
\hline \multirow[t]{11}{*}{... increased in: } & France & 8.9 & 9.3 & 9.7 \\
\hline & Germany & 7.3 & 6.9 & 9.6 \\
\hline & Italy & 8.4 & 9.7 & 10.6 \\
\hline & Austria & 4.1 & 4.9 & 5.4 \\
\hline & Greece & 6.7 & 7.0 & 8.0 \\
\hline & Finland & 5.5 & 8.0 & 15.4 \\
\hline & Iceland & 0.8 & 1.5 & 3.8 \\
\hline & Portugal & 6.1 & 4.9 & 5.8 \\
\hline & Spain & 19.1 & 19.8 & 20.9 \\
\hline & Sweden & 2.1 & 3.2 & 6.7 \\
\hline & Switzerland & 0.7 & 1.3 & 3.1 \\
\hline \multirow{8}{*}{... remained fairly stable in: } & Canada $^{2}$ & 8.3 & 9.0 & 8.5 \\
\hline & Japan & 2.5 & 2.5 & 2.7 \\
\hline & United States & 6.2 & 5.8 & 5.6 \\
\hline & Australia & 8.1 & 8.2 & 8.5 \\
\hline & Belgium $^{3}$ & 11.7 & 10.8 & 10.6 \\
\hline & Denmark $^{2}$ & 8.6 & 9.6 & 9.0 \\
\hline & Norway $^{2}$ & 3.1 & 4.2 & 5.1 \\
\hline & Turkey & 7.5 & 7.6 & 7.5 \\
\hline \multirow[t]{6}{*}{... decreased in: } & United Kingdom & 10.2 & 8.4 & 7.0 \\
\hline & Ireland & 15.3 & 16.0 & 12.8 \\
\hline & Netherlands & 8.0 & 7.0 & 6.3 \\
\hline & New Zealand & 4.7 & 7.3 & 6.0 \\
\hline & OECD structural unemployment rate ${ }^{4}$ & 7.0 & 6.8 & 7.1 \\
\hline & OECD actual unemployment rate ${ }^{4}$ & 7.7 & 6.1 & 7.7 \\
\hline
\end{tabular}

Notes:

1. Based on national definitions of unemployment. Structural unemployment data are based on Secretariat estimates of the non-accelerating wage rate of unemployment (NAWRU) made for the OECD Economic Outlook, 60, 1996.

The three-way country classification is based on a comparison of the change in structural unemployment over the period 1990-96 with the standard deviation of structural unemployment. The latter was calculated for each series and country over the 1986-96 period.

2. Canada, Denmark and Norway are estimated to have had an increasing structural unemployment rate in the late 1980s up to the beginning of the 1990 s.

3. Belgium had a decreasing structural unemployment rate in the second half of the 1980 s.

4. Weighted averages of the countries reported in the table.

Source: OECD Secretariat. 
9. It should be underlined that all OECD countries have taken some steps to combat high and persistent unemployment. But many have opted to implement only some of the recommendations rather than the entire prescription. For the eleven countries included in the first group in Table 1, those where the estimated structural unemployment rate increased over the period 1990-96, high and rising unemployment has so far been unable to bring about a collective desire to implement the broad thrust of the Jobs Strategy recommendations.

\section{Lesson 3: Concerns about the potential trade-off between equity and efficiency lie at the heart of whether OECD countries are willing to implement all the Jobs Strategy recommendations or not.}

10. One major reason for slow and sporadic implementation of the Jobs Strategy recommendations in some Member countries is the belief that implementing them may lead to a serious conflict with policy objectives concerning equity and social cohesion. This concern usually centres around the series of OECD recommendations designed to achieve greater flexibility in labour and product markets.

11. Some European countries argue that reforms to increase flexibility would lead to widening wage and income inequalities which their electorates would not accept. Other countries have countered this view by arguing that, judged in a dynamic perspective, there may be no conflict in objectives because reforms that result in higher employment could partly offset any tendency to greater wage inequality, and because mobility is important -- low-wage jobs can serve as a stepping stone to better paying jobs. However, there is little empirical work on the magnitude of such potential trade-offs.

12. Some countries have also expressed fears that implementing the Jobs Strategy in full would pose a threat to social cohesion. Against that, however, stands the argument that unemployment itself is the major threat to cohesion. In practice, action to reduce unemployment durably has rarely threatened cohesion, at least not in the longer term, with countries undertaking such action in line with their specific institutional and historical backgrounds. In the Netherlands and Ireland, the successful strategies included effective incomes policies, involving the social partners, to ensure consensual support for the reform process. In the United Kingdom and New Zealand, on the other hand, a sustained attempt at reforming the collective bargaining institutions met with considerable acceptance by the general public. Hence, the important conclusion that there are different approaches to successful implementation of the Jobs Strategy depending on the institutions and specific problems in each country.

\section{Lesson 4: There are significant complementarities to be reaped among structural reforms in different areas.}

13. Experience suggests that broad-based reforms are likely to be more effective than reforms focused in specific areas. For example, it seems to be important to back up reforms designed to achieve greater flexibility in labour markets with reforms designed to increase product market competition. More competitive and flexible product markets will ensure that labour demand reacts more swiftly and strongly to wage developments brought about by labour market reforms. 
Conversely, flexible labour markets will permit the rapid reallocation of labour set free as a result of product market competition.

14. Another example of such a lesson is the need to pay very careful attention to the interactions between active labour market policies and unemployment and related welfare benefits so as to enhance the effectiveness of active labour market policies. OECD analysis shows that it is vital to prevent active labour market measures from serving mainly as a vehicle to enable the unemployed to requalify for a renewed spell of benefit entitlements. Instead, they can be used as a work test, backed up by tight controls on benefit entitlements, to ensure that the unemployed, especially the long-term unemployed, are taking active steps to remain in contact with the labour market.

\section{Lesson 5: Macroeconomic conditions and policies and their interactions with structural policies are very important for labour market outcomes.}

15. The experience of the successful countries shows the importance of establishing an appropriate medium-term framework for macroeconomic stability, emphasising control over the public finances and inflation, thus enhancing the room for manoeuvre in macroeconomic policies.

16. It is also important for macro-economic policy to minimise cyclical fluctuations as far as is possible within the scope given by other policy targets and constraints. Countries with room for manoeuvre on the macroeconomic policy front have avoided sharp increases in actual unemployment and estimated structural unemployment. In contrast, countries with relatively large fluctuations in unemployment have often recorded stronger increases in structural unemployment because increases in unemployment which were cyclical in origin have tended, over time, to become translated into higher structural unemployment. Indeed, the countries where estimated structural unemployment rates rose the most in the 1990s are largely the ones where the cyclical volatility of unemployment increased the most.

\section{Lesson 6: What is needed now is further political action.}

17. The original Jobs Study and the subsequent follow-up work has produced a substantial body of analytical material, involving an extensive policy dialogue with OECD Member countries, and has permitted detailed country-specific policy recommendations for reducing unemployment on a durable basis to be derived for each Member country. This does not mean that nothing more can be learnt. On the contrary, the OECD Jobs Strategy is set to remain high on the policy agenda and to evolve further in coming years, with an update on progress due for OECD Ministers in April and a full review to be presented in 1999. Nevertheless, at this stage enough is known to permit countries to take further action to reduce unemployment. The constraints on such action today lie mostly in the political sphere. 


\section{Some specific areas of current concern}

18. While the thrust of the Jobs Strategy work has indeed been the need to push ahead on a number of fronts, the Organisation was asked to focus on a few specific issues for the London Conference. While the summary coverage of the four areas below focuses on these specific issues, the OECD work referenced at the end points to the broader coverage of the Jobs Strategy analysis which has been picked up in a systematic way in special chapters in the OECD's economic surveys of each of its Member countries. The four areas, whilst treated separately, are linked, as is made clear in the country surveys and in the following analysis.

\section{i) Tax and benefit reform}

19. If work does not pay, people will be more reluctant to work. For the majority in OECD countries, there are clear immediate financial incentives to work. But such incentives may be lacking for many people with low potential wages, particularly if they have children. In France, Germany and the United Kingdom, for example, long-term unemployed people with families would be unlikely to see their total family incomes increase by more than 15-20 per cent were they to take a typical low-paid job -- often barely enough to cover the increased costs of working, such as child care and transport. For these groups, social and labour market goals pursued by governments often clash. Benefits which are high enough to preserve a decent standard of living may mean that taking a job brings little or no extra income, trapping families in a state of dependency.

20. The present tax system also acts as a barrier to those trying to support themselves and their families through work. Taxes, inclusive of social countributions, reduce the return from working, and increase the cost of labour. Chart A shows that low-paid workers only receive between 80 per cent (Japan) and 50 per cent (Italy) of the wages employers are prepared to pay for their work. The lack of jobs suitable for low-skilled workers and the low net (after-tax) earnings provided by such jobs are caused in part by heavy taxation.

21. There are three ways to make work pay: (i) increase the skills and therefore the wages which individuals can receive; (ii) increase the incomes of those accepting low-wage jobs; or (iii) reduce the incomes of those out of work.

22. Upgrading skills and competences via effective lifelong learning strategies, including increased incentives for firms to invest in the skills of employees, represents the best long-term route to ensuring that work provides a decent standard of living. However, while such strategies should be vigorously pursued, they take time to implement and they are unlikely to work for everyone.

23. More recently, policy attention in several OECD countries has focused on the second possibility -- raising the incomes received by those in low-skilled jobs. One way to achieve this is to pay benefits or target tax cuts on those in work who have low family incomes. The family incomes of low-paid workers in Canada, Ireland, Italy, New Zealand, the United Kingdom and the 
United States are supplemented by sums varying from $\$ 500$ to $\$ 4000$ per year. Evidence suggests that these schemes achieve their main objectives: in-work poverty is reduced; the living standards of children are protected; and low-wage employment is increased. However, as earnings increase, the tax credits or benefits must be withdrawn -- otherwise, the budgetary cost of such measures would be prohibitive. This withdrawal, in turn, reduces the incentive of

\section{Chart A. Taxes on low paid workers (1996)}

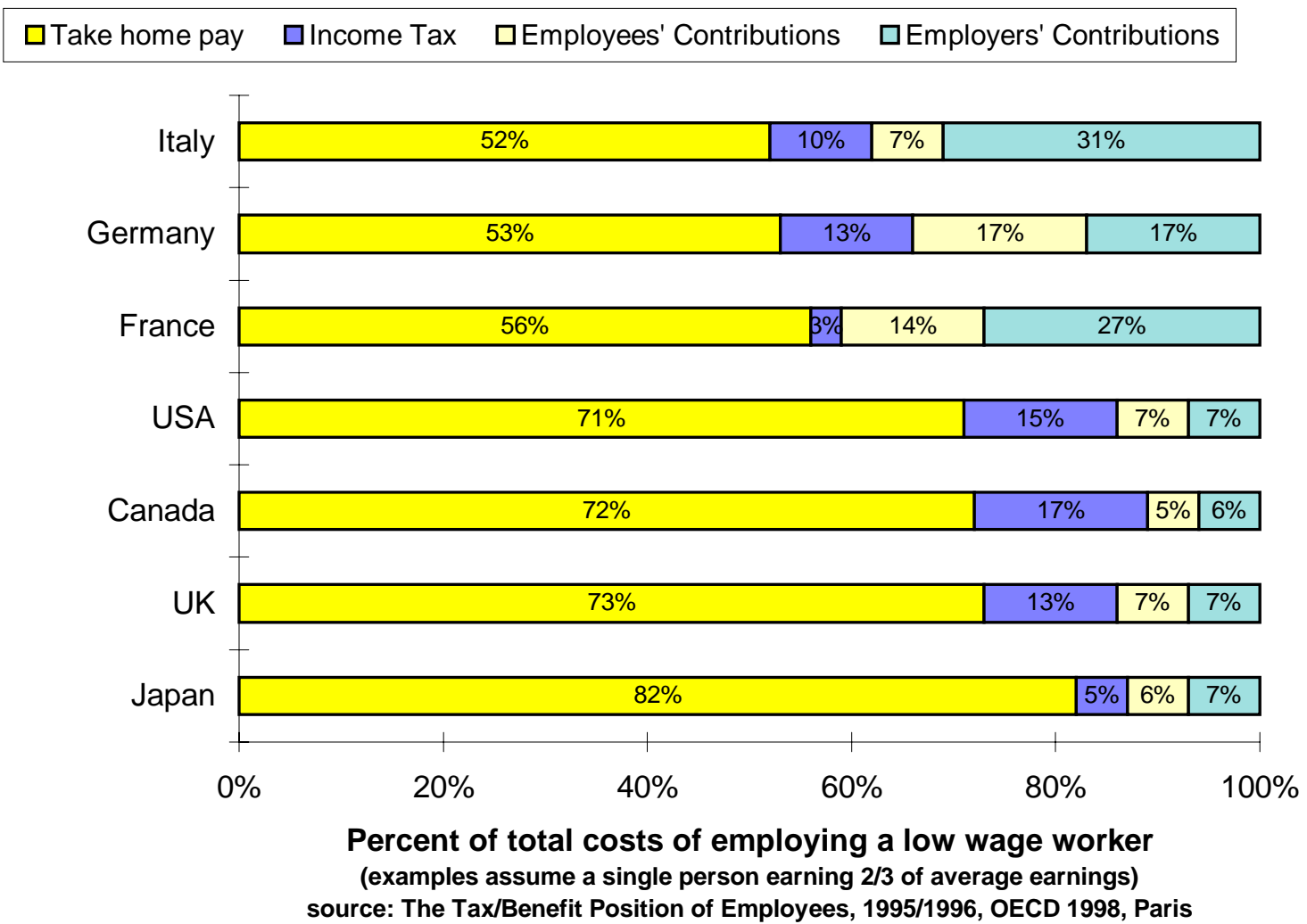

those receiving the benefit to increase their work effort in order to earn more. Moreover, the inevitable budgetary costs of these schemes have to be covered by raising tax rates elsewhere in the tax system, with potential negative impacts on incentives to work. As a result, employmentconditional tax credits or benefits must remain limited in size relative to average earnings.

24. Another route to the objective is to offer incentives to employers to hire low-paid workers whilst protecting in-work incomes through minimum wages. Countries such as France, Belgium and the Netherlands have embarked on payroll tax exonerations or reductions targeted to low-paid workers to encourage firms to hire more workers at the lower end of the earnings distribution. Although the implementation of such schemes has often been flawed in practice (overly-complex administration; frequent changes in regulations; low take-up, etc.) the rationale is clear. However, given public spending and deficit levels, labour taxes can only be reduced by 
changing the tax mix. Shifting the tax burden away from low-paid workers is, however, restricted by the lack of a suitable alternative tax base.

25. What these initiatives suggest is a growing agreement among OECD countries on the need to move towards an "employment-oriented social policy". Support should not be restricted to the inactive, as this inevitably throws up barriers to working. Paying people to work is better than paying them not to.

26. Reducing incomes of those without work -- the third possibility -- risks unacceptable reductions in the living standards of some of the most vulnerable households in society, especially where transfer levels are already low. Nevertheless, benefits have fallen relative to average earnings in some OECD countries. Whilst these reductions have been motivated mainly by a desire to redress public budgets rather than to improve work incentives, they have sometimes been associated with reduced benefit dependency. However, to have a significant effect on the number of benefit claimants, benefit levels would have to be cut substantially, and most OECD countries are unwilling to go far down this route.

27. Benefit claimants themselves report all sorts of barriers to work arising from the workings of the tax and benefit system, some of which can be overcome at limited cost -uncertainty about future incomes; worrying about how to manage until the first pay cheque is received; loss of special benefits which are only available to those without work, such as healthcare insurance or protection from creditors. Other elements of an employment-oriented social policy are undoubtedly expensive -- overcoming the absence of adequate, affordable childcare facilities; supplementing the family incomes of the low paid and subsidising their employers. Hence, there is little prospect that restructuring the welfare system can reduce costs substantially in the short term. But over the longer term, the payoff to reorienting the labour market and taxbenefit systems so that low-skilled workers can find work will nevertheless be substantial.

\section{ii) Increasing the effectiveness of active labour market policies (ALMPs)}

28. The need to shift public spending from passive income support to active reintegration measures for the unemployed, as suggested above, is a priority policy objective in many OECD countries. However, as Chart B shows, progress in terms of achieving this objective has been disappointing: for the OECD countries as a whole the share of active measures in total spending on labour market programmes did not increase between 1985 and 1996. The only noteworthy exception was France; this, however, was not due to higher spending on active measures but to a sharp reduction of spending on passive measures (in the form of early retirement benefits). The rise in actual unemployment in many countries in the 1990s partly accounts for the disappointing record of shifting spending towards active measures since passive income support is an entitlement whereas spending on active measures is discretionary and tends to get crowded out in periods of rising unemployment.

29. Another explanation for the disappointing record is concern that both active and passive measures are not designed and managed effectively enough. During periods of high and persistent unemployment, there is a strong tendency to put the main emphasis on the social objectives of these programmes to the neglect of their efficiency objectives. As a result, many active measures 
tend to become inadvertently "passive" in that they simply provide parking slots for the unemployed or serve to re-establish benefit entitlements for them.

Chart B. Active and passive labour market measures, 1996 $^{\mathrm{a}}$

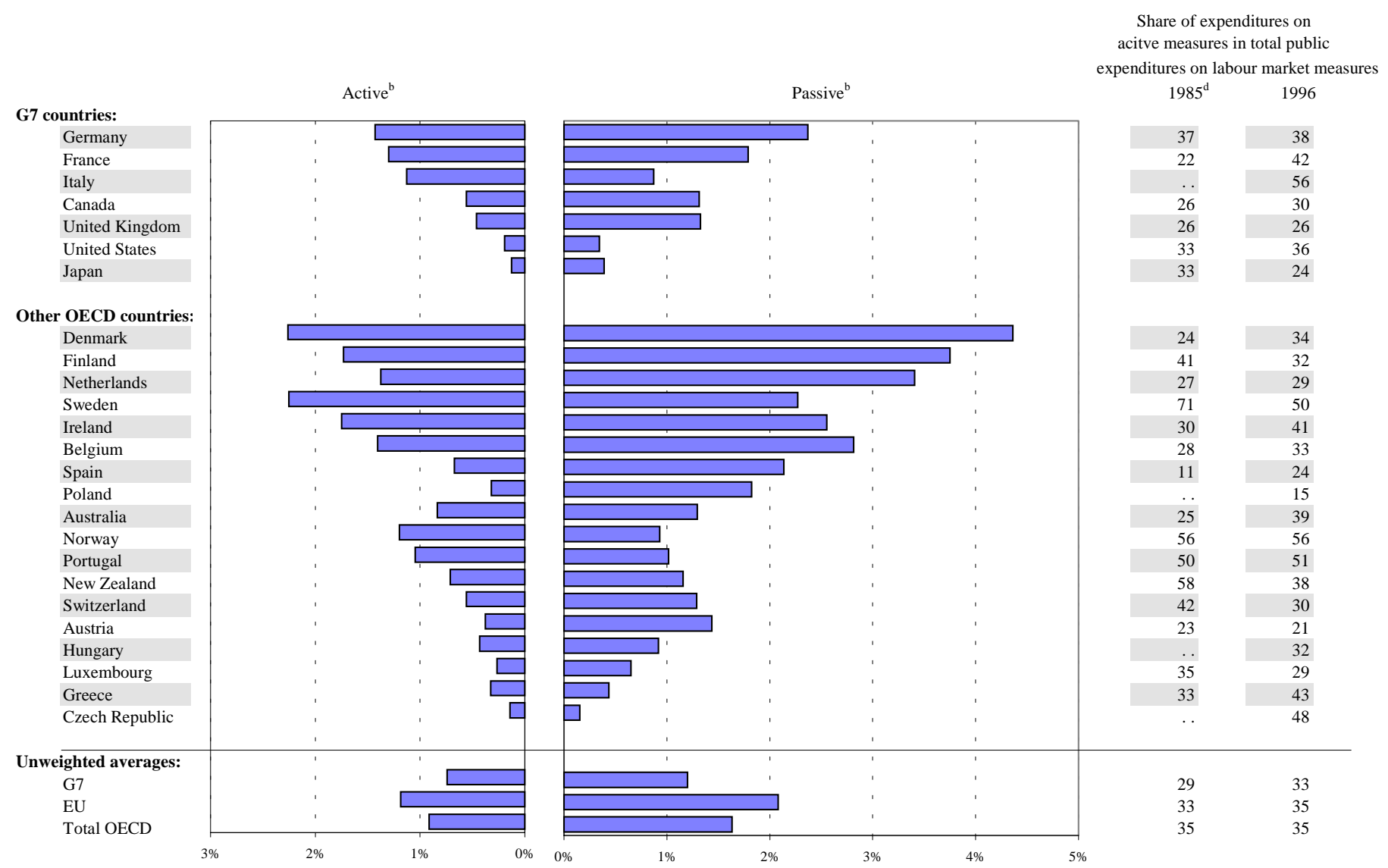

a) Within the G7 and non-G7 groupings countries are ranked in descending order of the ratio of total public expenditures on labour market programmes as a per cent of GDP. Data refer to 1995 for Australia, Belgium, France, Greece, Hungary, Italy, Japan, New Zealand, Sweden, the United Kingdom and the United States.

b) As a per cent of GDP. Active measures comprise placement, training and job creation measures. Passive measures comprise unemployment and related benefits.

c) The averages only include countries for which data are available in both years.

d) Data refer to 1986 for Denmark and Portugal, to 1987 for Japan.

Source: OECD Database on Public Labour Market Programmes.

30. OECD reviews of countries' experiences suggest that an integrated approach comprising job broking, unemployment benefit administration and the referral of job seekers to active labour market programmes can play an important role in enhancing the effectiveness of active measures. This conclusion is based on the experience of unemployment becoming a structural problem in many countries, especially those with generous benefit levels, unless an appropriate balance between income support, eligibility control and job-finding assistance is established and maintained efficiently over time.

31. In some countries with high and persistent unemployment, it is argued that the strict control of benefit entitlements, the application of work tests and the obligation on benefit recipients to contact placement offices on a regular basis is unnecessary because of a lack of available jobs. Experience in other OECD countries has shown that such a defeatist attitude is 
both unjustified and counterproductive. The work test can be extended into a so-called "activity" test, whereby job vacancies or slots on ALMPs are offered to benefit claimants in order to check whether they are really looking for work. The public employment service (PES) can take a variety of actions to increase the inflow of vacancies notified to it, thereby providing more opportunities for the unemployed to apply for jobs. Regular visits of job seekers to the placement office, the consultation of vacancy lists and the establishment and regular review of progress on a back-to-work plan are essential features of such a strategy.

32. Evaluation research conducted in some OECD countries suggests that job-search assistance programmes are cost-effective in terms of accelerating the chances of the unemployed to find a job. For more elaborate and costly labour market measures, such as training and employment programmes, the results seem to be mixed. Training, for instance, appears to work better for adults, such as women returning to the labour market after child rearing, than for disadvantaged youth. The effectiveness of training programmes tends to decline with the growing size of these programmes and the heterogeneity of the participants. In order to work, these programmes need to be well-targeted both to the characteristics of the participants and the requirements of the local labour market. The quality of the training and its closeness to a work environment are also important determinants of the outcome.

33. Most evaluations show that subsidised employment schemes -- be they in the private or public sectors -- are ineffective, being bedevilled by considerable dead-weight, displacement and substitution effects, and hence lead to small net employment gains. However, employment programmes may have a number of objectives other than creating additional jobs. They may enhance effective labour supply by helping individuals to keep in contact with the world of work, thus, maintaining their motivation and skills -- though no evaluation research is available on this point. For equity reasons, a case can also be made to subsidise the employment of the long-term unemployed even if this happens at the expense of the short-term unemployed.

34. Many OECD countries still have a long way to go in reducing current levels of unemployment, but all are faced with the challenge of accommodating the labour market consequences of technological change, globalisation and other on-going structural changes. This puts a high premium on effective active labour market policies and calls for more innovation, experimentation and evaluation in order to find out what works and why.

\section{iii) Entrepreneurship and job creation in small firms}

35. A key element of the Jobs Strategy set out in Box 1 above was to "nurture an entrepreneurial climate by eliminating impediments to, and restrictions on, the creation and expansion of enterprises". In this context the job creation potential of the small business sector has for some time been a source of considerable debate and was discussed at the Denver Summit last year. Firms with less than 500 employees account for over half of all employment in the United States, for over 60 per cent in Germany, France and the United Kingdom and for over 70 per cent in Canada, Italy and Japan, with small businesses having increased their share of total employment in recent years. There has been significant growth of self-employment in Canada and the United Kingdom, in part due to growth in the demand for new types of personnel and business services. Evidence shows that the bulk of new jobs created are in a small number of fast growth 
firms, often new technology-based firms with higher survival rates than other SMEs, which by their very nature are entrepreneurial. Entrepreneurs are essential agents of change and entrepreneurship fuels the drive for new economic and technological opportunities and efficient resource use.

36. High levels of entrepreneurial activity which contribute to economic growth and job creation are significantly influenced by government policies, including those which affect the regulation, financing and support of small, rapidly growing and innovative firms. The extent of entrepreneurial activity is often also ascribed to cultural attributes. Although legal frameworks and institutions reflect prevailing cultural attitudes, policies can be made more supportive of entrepreneurship within the confines of such attitudes and, more broadly, policies can change the attitudes themselves. Observers sometimes point to the more positive attitude to entrepreneurial activity in the United Kingdom during the 1980s and 1990s as a case in point.

37. The OECD is just completing a review of entrepreneurship to be presented to Ministers in April, which identifies key areas of policy that could be changed to promote entrepreneurship and, thereby, economic dynamism and job creation. The following recommendations about removing obstacles to small firm creation and growth emerge from that work.

38. Lowering the cost and risk of creating a business is a policy option which aims at increasing the number of businesses created. Creating a company involves complex and timeconsuming administrative costs in some countries. These can be reduced by eliminating unnecessary or complex registration requirements, and by co-ordinating the administrative requirements of the various government bodies through "one-stop shops". The closure of a failed enterprise can also be costly and, in some countries, it excessively discourages risk-taking by leaving failed entrepreneurs exposed to years of pursuit by creditors which, as a result, does not allow failed entrepreneurs a "second chance". Bankruptcy law must balance adequate protection for creditors with encouragement to entrepreneurs.

39. Reducing the tax compliance burden has moved to the top of the policy agenda in many countries. The administrative costs and compliance burden of the tax system are often cited by entrepreneurs as major impediments. Governments should review and, where appropriate, further reduce such compliance costs by, for example, simplifying tax language, reducing reporting requirements and making flat-rate tax arrangements for small firms.

40. Improving financing for small businesses is considered particularly important for growing enterprises. Governments in Canada, France, the United Kingdom and the United States have used loan guarantee schemes to mitigate the debt financing problems faced by small businesses. While such schemes have often increased the supply of credit to firms, they could be improved to eliminate market distortions and to ensure that those firms which receive support are those which most need it. Since many start-ups cannot expect to raise capital on formal, organised equity markets, private equity finance -- venture capital -- can be important.

41. Raising awareness of the benefits of entrepreneurship is another method of widening the pool of entrepreneurs. Some countries have recently created education programmes to introduce the concept of small business creation. For example, programmes have been developed in Canada 
for those of primary-school age through to universities in order to increase awareness of the opportunities presented by entrepreneurship. The private sector can also be encouraged to participate in such initiatives. However, these programmes must take a country-specific and long-term view and little is known about their effectiveness.

42. Finally there is a regional dimension of entrepreneurship which is important for policy. The nature of entrepreneurial activity often varies markedly, not only across countries but also across sub-national regions. Regional clusters of firms, based on local advantages and needs, can provide an environment particularly suited to entrepreneurship and small-scale firm development. Many such clusters exist, with "Silicon Valley" in California being probably the best known. A variety of locally designed and managed institutions may facilitate small business start-up and growth and encourage such clusters. These include: business incubators; advisory and information services; and training schemes of various sorts. More generally, given the differences across regions, the formulation and delivery of policies to promote the start-up and growth of small businesses can be more effectively delivered with the input of local authorities who are more aware of and sensitive to local conditions and needs.

\section{iv) Youth labour market problems and schooling}

43. The past two decades have seen a number of changes in schooling and in labour markets which have impacted greatly on young people. On the schooling side, more youth are staying on longer in education, with secondary education completion rates and tertiary participation rates higher than they have ever been. Concerning the labour market, the relative size of the youth population has declined significantly in almost all OECD countries, a factor which, on its own, would have been expected to raise their employment prospects. In addition, the composition of output has changed and jobs have shifted towards industries traditionally more "youth-intensive"; and, in many countries, youth earnings relative to adults have fallen. However, whatever the improvement in the labour market prospects of youth brought about by these trends it was apparently outweighed by other factors. Chart $\mathrm{C}$ shows that, while youth unemployment rates showed modest improvement or remained largely unchanged between 1985 and 1996, youth employment rates have dropped in almost all G7 countries, with the exception of Japan.

44. Of special concern, the employment prospects of out-of-school young men, who are likely to have fewer qualifications, have trended downward strongly over the past two decades. More unemployed youth are living in families with no other person in work. One-fifth or more of students, in half the OECD countries, still fail to complete upper secondary education or acquire useful vocational qualifications. Almost one-third of youth perform at the lowest literacy standards. And, the evidence is clear that both the unemployment and earnings prospects of young people who fail to complete upper secondary education are considerably worse compared with those who do at least acquire upper secondary qualifications.

45. Causes of under-achievement in school include family socio-economic status and low parental education, but these are only part of the problem. Education institutions have not accommodated successfully the range of student abilities; in many countries they fail to offer good opportunities for combined school-based and practical work-related learning. 
Chart C. Youth employment /population ratios and unemploym ent rates in the G-7 countries
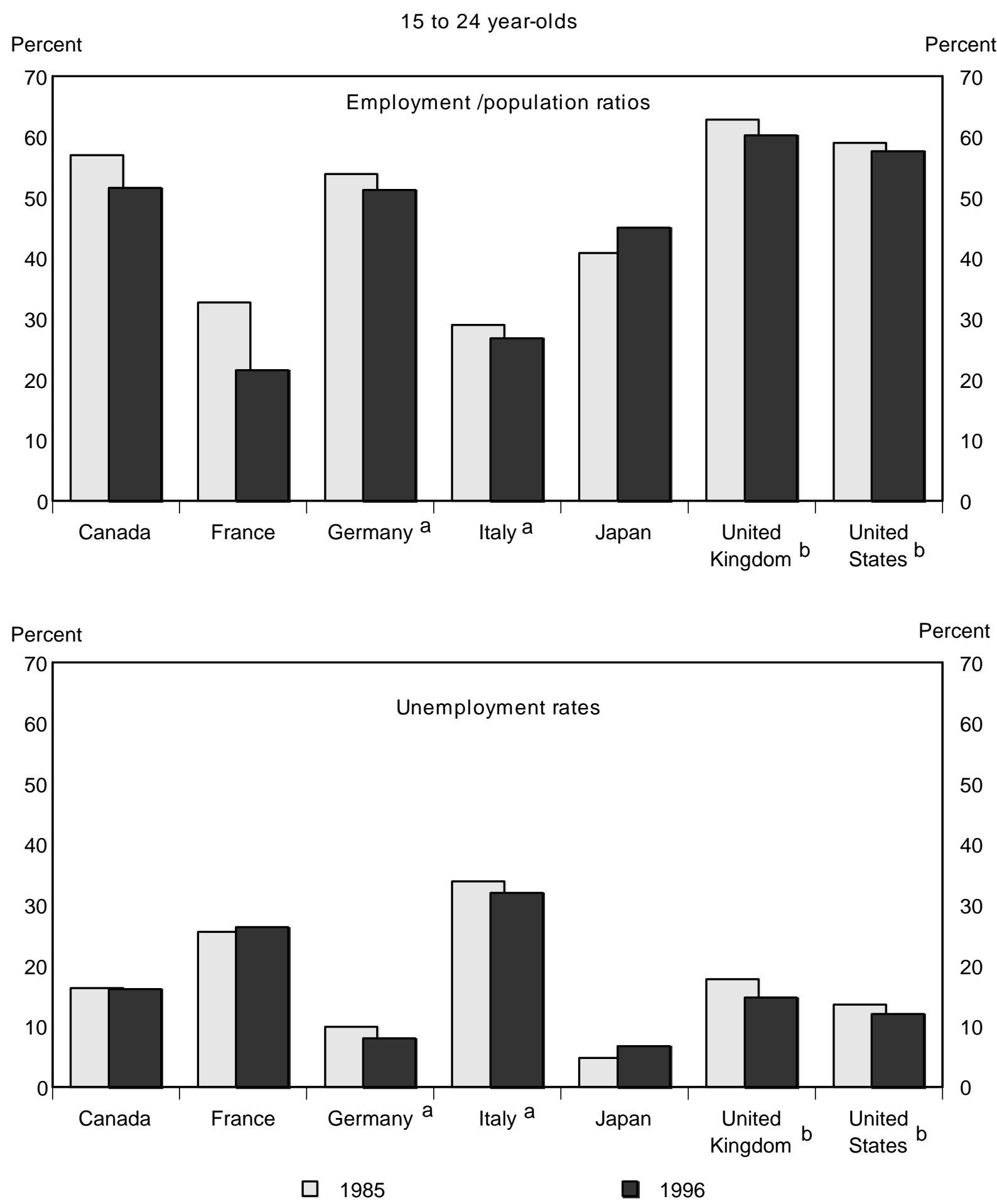

a) 1995. b) 16-24.

Source : OECD, Labour Force Statistics Database. 
46. Remedies have included emphasising parental and community involvement in schools. Curriculum reforms have aimed to combine classroom with work-related experience. More attention is given to early childhood development since evidence suggests that the earlier the intervention, the more likely it is to be effective. Higher education is channelling enrolments into advanced vocational and technical studies, and establishing more flexible pathways between general and technical studies and employment. Many governments also launched extensive training and other labour market programmes. But evaluations of a number of these programmes to date have not been encouraging.

47. A central focus for policy must be to distinguish youth at risk of marginalisation in the labour market, hopping from one dead-end job to another, and a smaller group of young people at risk of even more serious social and economic exclusion altogether. The latter consist largely of those youths who have dropped out of school early, sometimes because of major traumas in personal and family lives. Whatever improvements might be made in existing schooling arrangements are not likely to make major inroads into their problems. For them, measures that focus on integrated delivery of a range of support services, can prove useful, especially small-scale community networks that can provide close and continuing contacts with trusted adults, an approach used in some countries in their programmes for designated priority areas of educational disadvantage.

48. Youth joblessness is highly responsive to overall labour market developments and will improve most only when the causes of overall high and persistent unemployment are tackled. Nevertheless, a range of actions are worth considering for tackling specific problems faced by youth at risk of marginalisation in the labour market. Labour market programmes for disadvantaged youth must be combined with other programmes targeted on their specific needs in order to help overcome the multiple disadvantages they face. Employers can play an important role in improving the transition from education to work, as witnessed in those countries with strong apprenticeship systems such as Austria, Germany, Switzerland and Denmark. It is also important to pay due attention to the level of youth wages in order to ensure that they are not set at too-high levels which may deter employers from offering them jobs or training.

49. Youth labour market problems are complex, though perhaps no more so than for adults. But where there is a big difference, which societies ignore at their peril, is the fact that the first experience of working life -- or joblessness -- for youth, can scar their lives if they are not well prepared and guided in making the first few important steps. With this in mind the SecretaryGeneral has launched an initiative, endorsed by OECD Labour Ministers in October and the Kobe G8 Jobs Conference in November, to focus on problems of youth employment. 


\section{The contrasting labour market challenges in Russia}

50. Russia's current labour market problems are different in many respects from those in the other G8 countries. The Russian economy is undergoing a major economic transformation, a process necessitating a large-scale reallocation of labour at a time when government institutions and resources for addressing employment problems are quite limited. Although most transition countries faced similar systemic shocks, the changes in employment and unemployment in Russia were more gradual than elsewhere. Growth in unemployment in Russia has been more modest than most forecasts at the beginning of the transition period.

51. As the structural transformation process continues, there remain significant pressures for further adjustment in the Russian labour market. Roughly 40 per cent of Russian industrial enterprises are still categorised as "loss-making." On the positive side, a high degree of flexibility in the labour market has facilitated the reallocation process, helping to keep unemployment to date below double-digit levels. A significant absorption of labour into the shadow economy is believed by many to be another reason. But underemployment is substantial and significant numbers of workers appear to be facing deteriorating conditions of employment, e.g., shortened hours, unpaid vacations, and long delays in the payment of wages. The transition from school to work is especially difficult in this environment, and the educational system is only slowly adjusting to the new economic realities. At the same time, the delivery of social protection for the unemployed is hampered by limited funding and insufficient rationalisation and targeting of benefits.

\section{Labour market developments}

52. Following the introduction of market-oriented reforms in 1992, Russia experienced several years of deteriorating labour market conditions, but with considerable variation across regions. Although the level of unemployment may have stabilised recently, many enterprises are likely to downsize further as the restructuring process continues. While labour productivity fell sharply in the early years of transition, it has shown some positive growth in the last two years.

53. Labour force participation remains high at about 75 per cent of the working-age population. There has been some reallocation of labour across sectors, as employment declines in industry and construction have been partially offset by employment growth in services. Also, there appears to be substantial mobility within local labour markets, although much less across regions. Unemployment estimated according to "ILO" concepts rose throughout most of the transition period, peaking in Spring 1997 at 9.6 per cent of the labour force before subsequently declining to a rate of 8.9 per cent in the Fall. Registered unemployment is about one-third of "ILO" unemployment. Long-term unemployment has risen throughout the transition, now accounting for perhaps 40 per cent of total unemployment.

\section{Employment conditions and social protection}

54. Deteriorating employment conditions have affected many workers. High inflation eroded real wages during the early years of the transition period and enterprises have cut back slowly on the social benefits which they were obliged to provide to their workers during the Soviet era. By Fall 1997, average nominal monthly wages amounted to about US\$171. Wage arrears have also 
been significant. As of Fall 1997, arrears averaged about 120 per cent of the monthly wage bill in those sectors of the economy which are monitored. Through the Fall, administrative leaves, i.e., whereby workers are placed on leave at the behest of their employers, had affected over one tenth of the listed employees in medium and large enterprises. Short-time working also affected about 6.5 per cent of those employed in these enterprises. By one estimate, the combination of persondays lost due to short-time working and administrative leave in 1996 amounted to roughly 1.8 million full-time equivalent jobs.

55. Key elements of the social protection system depend on extra-budgetary funds financed largely by employers (i.e., for pensions, social security, employment security, and federal medical insurance). The functioning of these funds has been undermined by sizeable arrears due from employers -- problems analogous to those affecting the regular state budget. There has been an initiative to fold certain of these funds -- except the pension fund -- into the state budget, but it is not yet implemented.

\section{Main policy challenges}

56. Tackling the problems in the Russian labour market depends on policy actions that go well beyond the scope of labour market policy. These include reforms in taxation and other structural areas, which are necessary for improving the environment for entrepreneurship, business, and investment. The promotion of small business development, an area of stagnation in recent years, is important for maintaining the capacity of the economy to absorb future job losses.

57. The system of social protection will require rationalisation if it is to function effectively, delivering assistance to those most in need. Arrears on unemployment benefits currently range from two to twelve months depending on the region. Of the 89 regions, 63 have stopped transferring resources to the Employment Fund at the Federal level. A particular problem is the potentially adverse incentive that payment of unemployment benefits may bring in an environment where wages are not paid in full and on time. In view of resource constraints it is likely that certain benefit levels will need to be cut, for example, by doing away with the previous earningsrelated approach and establishing a flat-rate benefit scheme linked to subsistence minima and taking into account regional variations in the cost of living. The main alternative protection available from the state for the unemployed is social assistance, primarily provided though local governments drawing on local resources. The latter benefit is often provided on an ad hoc basis, sometimes in the form of material assistance or meals.

58. Enhancing the transition from school to work will require further restructuring in education. While the system continues to demonstrate certain strengths such as early childhood education, achievement of high literacy rates, and a high degree of professionalism, it also continues to exhibit some rigidity and inertia -- albeit with some variation across regions. Financial distress continues to limit the ability of the education system to implement reforms and wage arrears have damaged staff morale. There are particular problems of updating and broadening curricula, which previously focused on development of narrow specialisations, and ensuring the relevance of the education provided in light of the current needs in the labour market. 


\section{References to OECD work on Employment and Unemployment since 1992:}

The OECD Jobs Study (1994)

The OECD Jobs Study; Evidence and Explanations (1994)

The OECD Jobs Study: Implementing the Strategy (1995)

The OECD Jobs Study: Investment, Productivity and Employment (1995)

The OECD Jobs Study; Taxation, Employment and Unemployment (1995)

The OECD Jobs Strategy; Pushing Ahead with the Strategy (1996)

The OECD Jobs Strategy; Technology, Productivity and Job Creation (1996)

The OECD Jobs Strategy; Enhancing the Effectiveness of Active Labour Market Policies (1996)

Lifelong Learning for All (1996)

Macroeconomic Policies and Structural Reform (1996)

Implementing the OECD Jobs Strategy; Lessons from Member Countries' Experience (1997)

plus a more comprehensive analytical volume on Member Countries' Experience (1997)

The OECD Jobs Strategy; Making Work Pay (1997)

Effects of Shorter Working Hours, (box in OECD Economic Outlook, December 1997)

Literacy Skills for the Knowledge Society: Further Results from the Adult Literacy Survey (jointly OECD and Canadian Government) (1997)

Thematic reviews on Entrepreneurship and on Best Policy Practices in Technology, Productivity and Job Creation will be released later this year.

The OECD Economic Surveys over the period 1996-97 contained special chapters on "Implementing the OECD Jobs Strategy", including detailed recommendations for each country. Subsequent surveys have included an overview of the progress in implementing the Strategy. The initial Chapters for the G7 appeared in the Economic Surveys of the following dates:

$\begin{array}{ll}\text { United States } & \text { November } 1996 \\ \text { Japan } & \text { December } 1996 \\ \text { Germany } & \text { September } 1996 \\ \text { France } & \text { February } 1997 \\ \text { Italy } & \text { January 1996 } \\ \text { United Kingdom } & \text { May 1996 } \\ \text { Canada } & \text { November } 1996\end{array}$

See also the OECD Economic Survey of the Russian Federation, December 1997.

Recent issues of the OECD Employment Outlook include special chapters relevant to the Conference themes:

1996 Making Work Pay,

Earnings Inequality, Low-paid Employment and Earnings Mobility

Growing Into Work

Youth and the Labour Market over the 1980s and 1990s

1997 Earnings Mobility -- Taking a Longer Run View

Economic Performance and the Structure of Collective Bargaining

Is Job Insecurity on the Increase in OECD Countries?

1998 Minimum Wages, Employment and Poverty

(drafts) The Transition from Education to the Labour Market

Flexibility of Working Hours 


\section{STANDARDISED UNEMPLOYMENT RATES}

Per cent of labour force

Seasonally adjusted

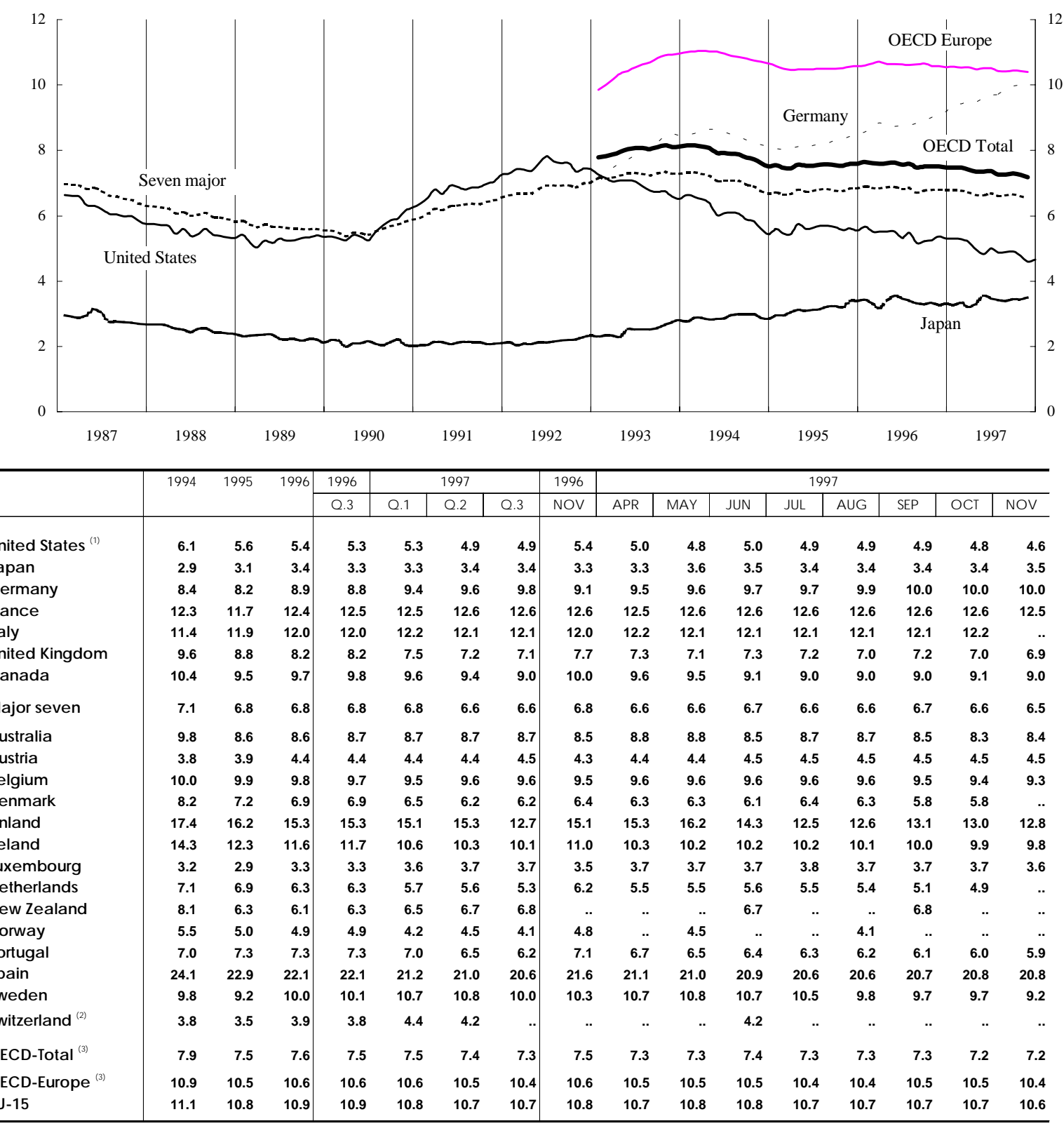

1. Revised data back to 1994. 2. Revised data back to 1991. 3. Only the countries listed are included in the area totals (with an additional estimation for Greece). Monthly figures include Secretariat estimates for countries which only compile quarterly rates.

Technical Note: The Standardised Unemployment Rates, compiled for 21 OECD countries, are based on definitions of the $13^{\text {th }}$ Conference of Labour Statisticians (generally referred to as the ILO guidelines). Under these definitions, the unemployed are persons of working age who, in the reference period, are without work, available for work and have taken specific steps to find work. The uniform application of the definitions results in estimates that are more internationally comparable than those based on national definitions. National unemployment data in some countries only include persons registered at government labour offices. Under the ILO definition, persons without work who are seeking employment through other means can also be classified as unemployed and registrants can be excluded if they worked or were not available for work. The Standardised Unemployment Rates for the European Union (EU) Member countries are produced by the Statistical Office of the European Communities (Eurostat). The OECD is responsible for the collection of data and calculation of Standardised Unemployment Rates for non-Eurostat countries. The Standardised Unemployment Rates shown here are calculated as the number of unemployed persons as a percentage of the civilian labor force (i.e the unemployed plus those in civilian employment). For a more detailed description of the methods of the OECDs Standardised Unemployment Rates, see the OECD publication Quarterly Labour Force Statistics. 


\section{LABOUR MARKET AND SOCIAL POLICY OCCASIONAL PAPERS}

Most recent releases are:

No. 30 PRIVATE PENSIONS IN OECD COUNTRIES - FRANCE (1997) Emmanuel Reynaud (available in French)

No. 29 OECD SUBMISSION TO THE UK LOW PAY MISSION (1997)

No. 28 OECD SUBMISSION TO THE IRISH NATIONAL MINIMUM WAGE COMMISSION (1997)

No. 27 CHILDCARE AND ELDERLY CARE: WHAT OCCUPATIONAL OPPORTUNITIES FOR WOMEN? (1997) (Susan Christopherson)

No. 26 THE CONCENTRATION OF WOMEN'S EMPLOYMENT AND RELATIVE OCCUPATIONAL PAY: A STATISTICAL FRAMEWORK FOR COMPARATIVE ANALYSIS (1997) (Damian Grimshaw and Jill Rubery)

No. 25 MAKING THE PUBLIC EMPLOYMENT SERVICE MORE EFFECTIVE THROUGH THE INTRODUCTION OF MARKET SIGNALS (1997) (Robert G. Fay)

No. 24 TRENDS IN SECRETARIAL OCCUPATIONS IN SELECTED COUNTRIES (1980-95) (Hilary Steedman) (1997)

No. 23 PRIVATE PENSIONS IN OECD COUNTRIES - AUSTRALIA (1997) (Hazel Bateman and John Piggott)

No. 22 THE DEFINITION OF PART-TIME WORK FOR THE PURPOSE OF INTERNATIONAL COMPARISONS (1997) (Alois van Bastelaer, Eurostat; Georges Lemaître, OECD; Pascal Marianna, OECD) (available in French)

No. 21 PRIVATE PENSIONS IN OECD COUNTRIES - THE UNITED KINGDOM (1997) (E. Philip Davis)

No. 20 OCCUPATIONAL CLASSIFICATION (ISCO-88): CONCEPTS, METHODS, RELIABILITY, VALIDITY AND CROSS-NATIONAL COMPARABILITY (1997) (Peter Elias)

No. 19 NET PUBLIC SOCIAL EXPENDITURE (1996) (Willem Adema, Marcel Einerhand, Bengt Eklind, Jórgen Lotz and Mark Pearson)

No. 18 ENHANCING THE EFFECTIVENESS OF ACTIVE LABOUR MARKET POLICIES: EVIDENCE FROM PROGRAMME EVALUATIONS IN OECD COUNTRIES (1996) (Robert G. Fay)

A complete list of available papers can be found on the internet site: http://www.oecd.org/els/papers/papers.htm, through which recent papers can be accessed directly. To receive a paper copy of this list or any particular papers, please send your name, organisation and full address:

Labour Market and Social Policy Occasional Papers

Directorate for Education, Employment, Labour and Social Affairs

OECD, 2, rue André-Pascal, 75775 PARIS CEDEX 16, FRANCE

\section{Mailing List for free of charge Labour Market and Social Policy Occasional Papers}

Please include the following name on the mailing list:

(write in capitals)

Name

Organisation

Address 


\section{RECENT OECD PUBLICATIONS IN THIS FIELD INCLUDE:}

\section{"OECD SOCIAL POLICY STUDIES" SERIES}

No. 21 FAMILY, MARKET AND COMMUNITY: EQUITY AND EFFICIENCY IN SOCIAL POLICY (1997)

No. 20 AGEING IN OECD COUNTRIES: A CRITICAL POLICY CHALLENGE (1996)

No. 19 CARING FOR FRAIL ELDERLY PEOPLE: POLICIES IN EVOLUTION (1996)

No. 18 INCOME DISTRIBUTION IN OECD COUNTRIES (1995)

\section{HEALTH POLICY STUDIES}

No. 8 HEALTH CARE REFORM: THE WILL TO CHANGE (1996)

No. 7 NEW DIRECTIONS IN HEALTH CARE POLICY (1995)

No. 6 INTERNAL MARKETS IN THE MAKING: HEALTH SYSTEMS IN CANADA, ICELAND AND UNITED $\operatorname{KINGDOM}(1995)$

\section{MISCELLANEOUS}

OECD HEALTH DATA (1997)

available in English or French on diskettes (Windows 3.11) or CD-ROM (Windows 95/NT or 3.11).

THE BATTLE AGAINST EXCLUSION

Social Assistance in Australia, Finland, Sweden and the United Kingdom (1997)

OECD EMPLOYMENT OUTLOOK July 1997 (published annually)

THE OECD JOBS STRATEGY:

Making Work Pay: Taxation, Benefits, Employment and Unemployment (1997)

THE OECD JOBS STRATEGY:

Enhancing the Effectiveness of Active Labour Market Policies (1996)

TRENDS IN INTERNATIONAL MIGRATION: CONTINUOUS REPORTING SYSTEM ON MIGRATION (SOPEMI) (1995)

For a full list, consult the OECD On-Line Bookstore on: http://www.oecd.org or write for a free written catalogue to the following address:

OECD Publications Service

2, rue André-Pascal, 75775 PARIS CEDEX 16

or to the OECD Distributor in your country 